\title{
Penentuan Segmen Pasar Produk Private Label Makanan Siap Saji (Studi Pada Circle K Surabaya)
}

\author{
Agusmuda Dharmadjie ${ }^{1}$, Pratikto², M. Hindun Pulungan ${ }^{3}$ \\ ${ }^{1}$ Mahasiswa Jurusan Teknologi Industri Pertanian Fakultas Teknologi Pertanian Unibraw \\ ${ }^{2}$ Staf Pengajar Jurusan Teknik Mesin Unibraw \\ ${ }^{3}$ Staf Pengajar Jurusan Teknologi Industri Pertanian Unibraw
}

\begin{abstract}
Abstrak
Segmentasi pasar memberikan peluang bagi peritel guna menyesuaikan produknya dengan permintaan konsumen. Penelitian ini bertujuan untuk mengetahui segmen pasar produk private label makanan siap saji di Circle K. Penelitian menggunakan analisis deskriptif untuk menggambarkan karakteristik konsumen dari variabel demografis, geografis, dan perilaku, analisis cluster K-Mean untuk menentukan segmen pasar dari variabel psikografis, analisis SWOT untuk menyusun faktor-faktor strategis perusahaan. Hasil penelitian menunjukkan : 1) segmen pasar yang terbentuk adalah mayoritas konsumen perempuan, berusia $15-25$ tahun, berpendidikan terakhir SMU, belum menikah, bekerja sebagai karyawan, tinggal di Surabaya, mengetahui makanan siap saji lewat teman, tujuan membeli mencoba-coba, membeli untuk makan, membeli sekali seminggu, kebiasaaan membeli mencoba yang baru, membeli ditemani teman, bersedia merekomendasikan, berminat membeli setelah mengetahuinya, tidak mudah bosan dengan makanan siap saji, menanggapi positif makanan siap saji sebagai makanan yang sehat dan bergizi, mempunyai kualitas dan nilai gizi yang baik, tidak membuat gemuk, dapat dikonsumsi oleh semua konsumen di segala usia, terjamin kebersihannya, dan mempunyai porsi yang cukup untuk sekali makan. 2) Kemungkinan alternatif strategis adalah menjaga kualitas produk, meningkatkan kualitas pelayanan, inovasi produk sesuai kebutuhan konsumen dengan harga yang terjangkau, menambah gerai, meningkatkan promosi, mempertahankan ciri khas produk, meningkatkan hubungan baik dengan pelanggan.
\end{abstract}

Kata kunci: makanan siap saji, private label, segmen pasar

\begin{abstract}
Segmentation market provides an opportunity for retailers to adapt their products to consumer demand. The study aims to determine the market segment of private label ready-to-eat foods products at the Circle $\mathrm{K}$. The study used a descriptive analysis to describe the characteristics of the consumer, K-mean cluster analysis to determine market segments, SWOT analysis to formulate company strategic factors. The results showed: 1 ) market segments that form the majority of consumers are women, aged 15-25 years, high school education background, unmarried, working as an employee, living in Surabaya, know ready-to-eat food through friends, buy to eat, buy once a week, try a new buying habits, willing to recommend, interested in buying after informed, it is not easy to get bored with ready-to-eat food, a positive response to ready-to-eat food as healthy and nutritious food, has the quality and nutritional value good, does not make fat, can be consumed by all consumers in all ages, guaranteed clean, and has a sufficient portion for one meal. 2) The possibility of strategic alternatives is maintaining product quality, improve service quality, product innovation, add outlets, increase promotion, maintaining the basic characteristics of products, improving relationships with customers.
\end{abstract}

Keywords: ready-to-eat, private label, market segments

\section{PENDAHULUAN}

Kebutuhan makan dan minum merupakan kebutuhan yang tidak dapat tergantikan dengan kebutuhan-kebutuhan yang lainnya, sehingga kebutuhan makan dan minum ini ditempatkan pada urutan pertama sebagai dasar kebutuhan manusia.

Alamat korespondensi

Agusmuda Dharmadjie

E-mail : agusciut@yahoo.com

Alamat : Jurusan Teknologi Industri Pertanian Fakultas Teknologi Pertanian Unibraw
Pola kehidupan yang serba cepat, praktis, dan modern menyebabkan munculnya kebutuhan yang serba praktis, dimana salah satunya adalah produk makanan yang siap saji. Permintaan akan makanan siap saji cukup besar, dimana daya tarik utamanya adalah kenyamanan, ketersediaannya, dan membutuhkan waktu yang singkat, untuk penyiapan sebelum mengkonsumsinya [1].

Produk makanan siap saji yang tersedia di pasar semakin banyak ragamnya, sehingga konsumen semakin bebas dalam memilih produk makanan siap saji dan menyebabkan terjadinya 
persaingan antar peritel dalam memperebutkan dan mempertahankan konsumennya. Kondisi persaingan persaingan antar peritel menyebabkan peritel mengembangkan konsep tokonya, dengan membuat toko memiliki suasana nyaman, menyediakan produk bermutu dengan harga yang terjangkau [2].

Produsen mampu menghasilkan produknya dengan berbagai merek, jenis, kualitas, dan harga. Ritel dapat membeli merek yang sudah terkenal, mengembangkan sendiri produk private label, atau kombinasi keduanya. Produk private label dibuat oleh peritel dengan nama perusahaan ritel yang memproduksinya [3].

Circle $K$ sebagai salah satu convenience store yang menjual produk private label makanan siap saji Take Away Café harus dapat menyediakan makanan siap saji yang bisa memenuhi keinginan konsumennya. Produk makanan siap saji Take Away Café ini termasuk produk yang relatif baru yang dijual di gerai Circle $K$ Indonesia. Konsumen makanan siap saji mempunyai karakteristik yang heterogen, dimana keinginan dan kebutuhan konsumen akan makanan siap saji tidak sama. Kondisi ini akan membuat Circle $K$ kesulitan dalam membuat makanan siap saji yang sesuai dengan harapan semua konsumennya.

Juga banyaknya convenience store yang muncul di Surabaya dan menjual makanan siap saji, membuat mereka berlomba-lomba untuk menarik minat dan perhatian konsumen sehingga menimbulkan persaingan yang cukup ketat. Circle $K$ sebagai salah satu gerai atau convenience store yang menjual produk private label makanan siap saji banyak mendapatkan saingan dari gerai lainnya yang menjual makanan siap saji sejenis. Guna memenangkan persaingan, Circle $K$ perlu menjual makanan siap saji yang dapat memenuhi kebutuhan konsumennya.

Menurut [4], guna meningkatkan persaingan setiap perusahaan harus dapat memenangkan persaingan dengan menampilkan produk yang terbaik, sehingga dapat memenuhi selera konsumen yang selalu berkembang dan berubahubah. Guna memenuhi hal tersebut, maka peritel harus mengembangkan dan menerapkan strategi segmentasi pasar [5]. Strategi segmentasi pasar membagi konsumen pasar ke dalam kelompokkelompok yang teridentifikasi mempunyai kebutuhan produk yang relatif serupa, sehingga memudahkan peritel untuk memenuhi kebutuhan konsumennya.

Circle $K$ sebagai salah satu convenience store yang menjual produk private label makanan siap saji banyak mendapatkan saingan dari gerai lainnya yang menjual produk sejenis. Circle $K$ perlu kritis mengenai kebutuhan dari konsumen makanan siap saji, sehingga Circle $K$ perlu mensegmentasikan pasar atau konsumen yang heterogen ke dalam kelompok yang relatif homogen, sehingga dapat memuaskan kebutuhan konsumen.

Perumusan masalah dalam penelitian ini adalah segmen pasar yang manakah mengkonsumsi produk private label makanan siap saji di Circle K. Adapun tujuan penelitian ini adalah untuk mengetahui segmen pasar produk private label makanan siap saji di Circle $K$ berdasarkan karakteristik demografis, geografis, psikografis, dan perilaku.

\section{METODE PENELITIAN}

Penelitian yang dilakukan merupakan penelitian deskriptif dengan menggunakan pendekatan kualitatif dan kuantitatif. Pendekatan kualitatif dengan melakukan wawancara, sedangkan pendekatan kuantitatif dilakukan dengan menyebarkan kuisioner.

Sampel yang diambil dalam penelitian ini adalah konsumen yang datang ke Circle $K$ Surabaya dan sedang membeli dan atau mengkonsumsi makanan siap saji private label Circle $K$ pada saat penelitian dilakukan. Jumlah sampel ditentukan sebanyak 100 sampel, dimana untuk analisis cluster memerlukan sampel setidaknya 100 atau lebih [6].

Data diperoleh dengan penyebaran kuisioner, wawancara dengan staf Circle $K$, dan bagian marketing, serta studi pustaka.

Teknik pengambilan sampel yang digunakan adalah non probability sampling dengan teknik penentuan sampel adalah purposive sampling. Tidak semua konsumen Circle $K$ diberikan lembaran kuisioner, hanya konsumen yang sedang membeli dan atau mengkonsumsi makanan siap saji private label Circle $K$ dan berusia 15 tahun ke atas. Kuisioner yang digunakan merupakan kuisioner tertutup dengan menggunakan skala Likert. Variabel dan indikator dalam penelitian ini adalah :

a. Variabel demografis dengan indikator jenis kelamin, umur, pendidikan terakhir, status pernikahan, pekerjaan.

b. Variabel geografis dengan indikator wilayah tempat tinggal.

c. Variabel perilaku dengan indikator darimana mengetahui produk, tujuan membeli, keperluan membeli, frekuensi membeli, kebiasaan membeli, siapa yang 
menemani, dan kesediaan memberikan rekomendasi.

d. Variabel psikografis dengan indikator gaya hidup.

Analisis data menggunakan analisis deskriptif untuk menggambarkan karakteristik konsumen dari variabel demografis, geografis, dan perilaku, analisis cluster K-Mean (dengan bantuan Program SPSS 16 for windows) untuk menentukan segmen pasar dari variabel psikografis. Guna melengkapi metode ini, maka digunakan analisis SWOT untuk menyusun faktor-faktor strategis perusahaan.

\section{HASIL DAN PEMBAHASAN}

\section{Profil Perusahaan}

Circle $K$ merupakan waralaba toko kelontong atau minimarket internasional yang berasal dari Amerika Serikat. Sekarang, Circle $K$ dimiliki dan dioperasikan oleh jaringan waralaba toko retail terbesar di Kanada yang bernama Alimentation Couche-Tard. Sampai saat ini, Circle $K$ memiliki lebih dari 4000 gerai internasional yang berada di luar Amerika dan 2100 gerai yang tersebar di seluruh wilayah Amerika.

Sejarah Circle $K$ dimulai pada tahun 1951 ketika Fred Harvey membeli tiga toko bahan makanan Kay's Foodstore di El Paso, Texas dan mengubah nama toko tersebut menjadi Circle $K$. Sejak saat itu, secara perlahan Circle $K$ mulai berkembang membesar dengan mengakuisisi berbagai minimarket lain. Circle $K$ mulai terjun ke pasar internasional pada tahun 1979, dengan mengadakan lisensi pembukaan gerai internasional pertamanya di Jepang.

Program waralaba diperkenalkan pada tahun 1999, dengan tujuan untuk mendukung operator yang ingin membangun bisnis dengan merek convenience store yang terkemuka. Pada tahun 2003, perusahaan retail convenience store terbesar di Kanada yang bernama Alimentation Couche-Tard (ACT) mengakuisisi merek Circle $K$.

Circle $K$ pertama kali hadir di Indonesia pada tahun 1986 di kota Jakarta, di Jalan Panglima Polim Jakarta Selatan oleh Yayasan Trisakti dan merupakan convenience store pertama yang hadir di Indonesia. Pada tahun 1989, Circle $K$ diambil alih oleh PT. Circleka Indonesia. Circle $K$ kemudian merambah ke luar Jakarta dengan membuka gerai di Bali (1996), Yogyakarta (2000), Bandung (2001), dan diikuti beberapa kota besar seperti Batam, Makasar, dan Surabaya.

Circle $K$ merupakan perusahaan ritel dengan konsep convenience store yang menyediakan barang-barang yang segera digunakan. Circle $K$ beroperasi penuh selama 24 jam sehari, fokus pada kepuasan pelanggan dengan memberikan kecepatan pelayanan, kebersihan dan kerapian gerai, keramahan pramuniaga, dengan didukung oleh suasana gerai yang menyenangkan.

\section{Karakteristik Produk Makanan Siap Saji}

Makanan siap saji dapat diartikan sebagai makanan yang dikemas, mudah disajikan, praktis, atau diolah dengan cara yang sederhana. Makanan siap saji berarti makanan yang biasanya dikonsumsi dalam keadaan yang sama seperti saat dijual, dapat dalam bentuk mentah atau matang, panas atau dingin, dan dapat dikonsumsi tanpa melalui perlakuan panas lebih lanjut termasuk pemanasan ulang.

Bentuk makanan siap saji yang tersedia di Circle $K$ dibedakan menjadi 3 kelompok yaitu :

a. Makanan siap saji yang dapat langsung dikonsumsi, seperti cold sandwich.

b. Makanan siap saji yang memerlukan penambahan air panas.

c. Makanan siap saji yang memerlukan pemanasan sebentar dengan microwave (sekitar 3-5 menit).

Berdasarkan produsennya, makanan siap saji yang terdapat di Circle $K$ dibedakan menjadi :

a. Makanan siap saji dari produsen umum, yaitu produsen yang membuat produk makanan siap saji dan menjual produknya dengan nama atau merek dari produsen tersebut dan umumnya menjual produk makanan siap saji yang hanya memerlukan penambahan air panas saja. Makanan siap saji kelompok ini berupa mie instan dalam wadah bentuk cup, seperti Nissin Cup Noodle, Mie Sedap Cup, Pop Mie, Mie ABC Cup, Myojo, Nissin Newdles, Eat \& Go, Nissin Yakisoba. Selain mie instan, juga terdapat bubur kentang instan Potayo.

b. Makanan siap saji dari produsen khusus, yaitu produsen yang membuat makanan siap saji dan menjual produknya dengan menggunakan nama atau merek dari Circle K, yaitu Take Away Café. Produk inilah yang dinamakan produk private label makanan siap saji dari Circle $K$. Produsen khusus hanya memproduksi makanan siap saji yang telah disepakati dengan Circle $K$ dan tidak boleh menjual produk yang sama di gerai selain gerai dari Circle $K$.

Produk Take Away Café ini merupakan produk makanan siap saji yang memerlukan pemanasan sebentar dengan microwave (sekitar 
3 sampai 5 menit) sebelum dikonsumsi. Lamanya waktu pemanasan tergantung pada jenis makanan siap saji, dan waktu pemanasan tercantum pada kemasan produk. Makanan siap saji ini dibedakan dalam 3 kelompok yaitu :

a. Fresh rice. Makanan siap saji yang berupa nasi dengan lauk pauknya. Makanan siap saji ini terdiri dari varian menu seperti Nasi Kare Ayam, Nasi Ayam Teriyaki, Nasi Daging Sapi Lada Hitam, Nasi Uduk, Nasi Goreng Oriental, Nasi Kuning, Nasi Goreng Seafood, Nasi Rendang Sapi, Nasi Ayam Lada Hitam.

b. Fresh noodle. Makanan siap saji yang berupa pasta, mie, bihun, atau kwetiaw (bukan berupa nasi) dengan lauk pauknya. Makanan siap saji ini terdiri dari varian menu seperti Fettucini Carbonara, Spaghetti Bolognese, Macaroni Cheese, Mie Goreng, Mie Sapi Cabe Hijau, Mie Bakso Ayam, Bihun Goreng, Kwetiaw Siram.

c. Fresh dessert. Makanan siap saji yang berupa produk bakery, seperti kelompok Danish, Puff, Pie, Croisant dengan berbagai rasa atau isian tengah (centre fill).

Produk makanan siap saji Take Away Café yang berupa fresh rice dan fresh noodle menggunakan kemasan food grade tray, sehingga dapat langsung digunakan sebagai tempat makan setelah dipanaskan. Petunjuk penyajian, lama pemanasan, dan tanggal kadaluarsa terlihat jelas pada kemasan. Petugas atau pramuniaga selalu siap untuk membantu proses pemanasan makanan siap saji apabila makanan siap saji hendak dikonsumsi di gerai Circle $K$, dan juga akan diberikan sendok untuk memudahkan dalam mengkonsumsinya.

\section{Karakteristik Responden}

Karakteristik responden berdasarkan segmentasi demografis mayoritas konsumen berjenis kelamin perempuan, berusia $15-25$ tahun, berpendidikan terakhir SMU, belum menikah, bekerja sebagai karyawan. Berdasarkan segmentasi geografis, mayoritas konsumen berasal dari Kota Surabaya. Berdasarkan segmentasi perilaku, mayoritas konsumen mengetahui adanya makanan siap saji private label di Circle $K$ lewat teman, membeli dengan tujuan untuk mencoba-coba, membeli guna keperluan untuk makan, membeli sekali dalam seminggu, mempunyai kebiasaaan membeli dengan mencoba yang baru, membeli dan atau mengkonsumsi dengan ditemani oleh teman, dan bersedia merekomendasikan makanan siap saji.

\section{Pembentukan Cluster dan Penentuan Segmen Pasar}

Hasil analisis cluster diperoleh 3 buah cluster, dimana cluster 1 terdapat 54 responden, cluster 2 terdapat 8 responden, dan cluster 3 terdapat 38 responden. Tidak terdapat responden yang hilang (missing), yang berarti semua responden lengkap terbagi dalam tiga cluster.

Berdasarkan hasil analisis Cluster, maka Circle $\mathrm{K}$ dapat fokus pada segmen yang paling banyak yaitu pada cluster satu. Adapun uraian konsumen pada segmen ini adalah :

a. Konsumen suka atau tertarik untuk mencoba jenis-jenis makanan baru, termasuk produk private label makanan siap saji yang dijual digerai Circle $K$. Mereka berminat membeli dan atau mengkonsumsi makanan siap saji setelah mengetahui adanya produk tersebut. Makanan siap saji yang dijual sangat bervariasi, sehingga tidak membosankan, bahkan beberapa menu merupakan menu favorit dari konsumen. Bagi mereka, produk Take Away Café mudah didapatkan dan selalu tersedia pada saat diperlukan (jarang kosong).

b. Konsumen yang memperhatikan pengaturan tata letak dan pelayanan dari pramuniaga. Peletakan produk Take Away Café di dekat minuman dan makanan siap saji lainnya, memudahkan konsumen untuk melihat produk tersebut dan menarik perhatian konsumen untuk membeli dan atau mengkonsumsinya. Pelayanan yang memuaskan, dimana pramuniaga selalu membantu persiapan makanan hingga siap dikonsumsi, menyebabkan konsumen memilih mengkonsumsi makanan siap saji.

c. Konsumen yang memperhatikan kualitas dari makanan siap saji. Konsumen menanggapi makanan siap saji Take Away Café sebagai makanan yang sehat dan bergizi. Mereka mengkonsumsi makanan siap saji karena nilai gizinya dan mengkonsumsi makanan siap saji tidak membuat gemuk. Makanan siap saji dapat dikonsumsi oleh semua konsumen di segala usia.

d. Konsumen yang memperhatikan kepraktisan dari makanan siap saji. 
Faktor kemudahan dalam penyajian dan konsumsinya, membuat makanan siap saji menjadi pilihan bagi konsumen dengan tingkat aktivitas tinggi dan waktu yang padat. Penyiapan produk tidak memerlukan waktu yang lama dan dapat dikonsumsi langsung pada wadahnya sehingga sangat praktis. Makanan siap saji tersedia dalam porsi yang cukup untuk sekali makan.

e. Konsumen yang memperhatikan kemasan dari makanan siap saji. Kemasan makanan siap saji kuat dan tidak mudah rusak, sehingga terjamin kebersihannya. Desain kemasan bervariasi dan menarik, dengan etiket dan masa kadaluarsa yang jelas dan mudah dibaca.

f. Konsumen dalam melihat harga dari makanan siap saji. Harga makanan siap saji dianggap tidak terlalu mahal dan masih terjangkau, serta sesuai atau sebanding dengan kualitasnya. Kegiatan promosi makanan siap saji yang dilakukan menarik minat pembelian makanan siap saji oleh konsumen.

\section{Analisis SWOT}

\section{Identifikasi Faktor Internal}

Faktor internal perusahaan meliputi kekuatan dan kelemahan dari perusahaan.

1. Kekuatan.

a. Kualitas produk. Produk makanan siap saji dinilai memiliki kualitas dan nilai gizi yang baik.

b. Variasi produk. Produk Take Away Café yang dijual di Circle $K$ bervariasi dengan menu yang beragam.

c. Harga bersaing. Harga makanan siap saji yang dijual di Circle $K$ tidak beda jauh dengan harga makanan di rumah makan atau food court.

d. Kualitas pelayanan. Pramuniaga selalu membantu persiapan produk makanan siap saji Take Away Café.

2. Kelemahan.

a. Kurangnya promosi. Aktivitas promosi Take Away Café yang dilakukan oleh Circle $K$ dirasa belum maksimal.

b. Kurangnya varian menu. Varian menu yang tersedia umumnya merupakan makanan yang tidak berkuah.

c. Kurangnya jumlah gerai. Gerai dari Circle $K$ yang berada di Surabaya masih terbatas atau belum banyak.

\section{Identifikasi Faktor Eksternal}

Faktor eksternal perusahaan meliputi peluang dan ancaman terhadap perusahaan.

1. Peluang.

a. Kebutuhan masyarakat kota Surabaya akan produk yang praktis. Masyarakat Surabaya didominasi oleh kalangan muda dengan aktivitas yang tinggi dan waktu yang tidak terlalu banyak membutuhkan produk yang praktis, sehingga makanan siap saji dapat menjadi alternatifnya.

b. Perubahan perilaku dan selera konsumen. Adanya penghasilan yang cukup dan pergeseran pola belanja dengan lebih suka berbelanja di pasar modern, dapat menyebabkan perubahan pola konsumsi pula.

c. Kemampuan konsumen. Konsumen dari Circle $K$ umumnya adalah kalangan muda yang sudah mempunyai penghasilan sendiri atau mendapatkan dukungan keuangan dari keluarga, sehingga mereka dapat membiayai kebutuhannya.

d. Pemasok yang berkualitas. Produk makanan siap saji yang dijual di Circle $K$ dipasok oleh perusahaan yang telah ditentukan oleh pihak Circle $K$ dengan beberapa kriteria.

2. Ancaman.

a. Keberadaan gerai yang sejenis. Munculnya gerai yang sejenis dengan produk yang hampir sama membuat ketatnya persaingan.

b. Perusahaan pendatang baru. Pertumbuhan kebutuhan makanan siap saji meningkatkan jumlah perusahaan yang ikut memproduksi makanan siap saji, sehingga produk makanan siap saji yang diproduksi dan dijual juga akan semakin beragam.

c. Paradigma masyarakat tentang makanan siap saji. Masyarakat masih menganggap makanan siap saji sama dengan junk food yang tinggi lemak dan membuat gemuk.

\section{Matriks IFAS dan EFAS}

Hasil analisis terhadap faktor internal dalam matriks IFAS pada Tabel 1 Matriks IFAS, menunjukkan bahwa faktor yang menjadi kekuatan utama perusahaan adalah kualitas produk dengan nilai skor bobot tertinggi sebesar 0,80 , sedangkan kelemahan utama adalah 
kurangnya varian menu dan kurangnya jumlah gerai dengan nilai skor bobot terkecil sebesar 0,20 . Hasil analisis perhitungan faktor-faktor internal diperoleh total skor bobot sebesar 2,85. Nilai ini berada di atas nilai 2,50 yang menunjukkan bahwa posisi internal perusahaan cukup kuat, dimana perusahaan memiliki kemampuan menggunakan kekuatan dan mengatasi kelemahan internal.

Tabel 1. Matriks IFAS

\begin{tabular}{|l|c|c|c|}
\hline \multicolumn{1}{|c|}{ Faktor Internal } & Bobot & Peringkat & Skor Bobot \\
\hline KEKUATAN & 0,20 & 4,00 & 0,80 \\
\hline 1. Kualitas produk & 0,15 & 3,00 & 0,45 \\
\hline 2. Variasi produk & 0,10 & 3,00 & 0,30 \\
\hline 3. Harga bersaing & 0,20 & 3,00 & 0,60 \\
\hline 4. Kualitas pelayanan & & \multicolumn{2}{l|}{} \\
\hline KELEMAHAN & 0,15 & 2,00 & 0,30 \\
\hline 1. Kurangnya promosi & 0,10 & 2,00 & 0,20 \\
\hline 2. Kurangnya varian menu & 0,10 & 2,00 & 0,20 \\
\hline 3. Kurangnya jumlah gerai & 1,00 & & 2,85 \\
\hline TOTAL &
\end{tabular}

Hasil analisis terhadap faktor eksternal dalam matriks EFAS pada Tabel 2 Matriks EFAS, menunjukkan bahwa faktor yang menjadi peluang utama perusahaan adalah kebutuhan masyarakat kota Surabaya akan produk yang praktis dan perubahan perilaku dan selera konsumen yang semakin berkembang, dengan nilai skor bobot tertinggi sebesar 0,80 , sedangkan ancaman utama perusahaan adalah paradigma masyarakat tentang makanan siap saji dengan nilai skor bobot terkecil sebesar 0,15. Hasil analisis perhitungan faktor-faktor eksternal diperoleh total skor bobot sebesar 3,05. Nilai ini berada di atas nilai 2,50 yang menunjukkan bahwa perusahaan telah mampu merespon faktor eksternal, dengan memiliki strategi yang efektif untuk memanfaatkan peluang guna mengatasi atau meminimalkan ancaman eksternal.

Tabel 2. Matriks EFAS

\begin{tabular}{|l|c|c|c|}
\hline \multicolumn{1}{|c|}{ Faktor Eksternal } & Bobot & Peringkat & Skor Bobot \\
\hline \multicolumn{4}{|l|}{ PELUANG } \\
\hline 1. Kebutuhan masyarakat kota Surabaya akan produk yang praktis & 0,20 & 4,00 & 0,80 \\
\hline 2. Perubahan perilaku dan selera konsumen yang semakin berkembang & 0,20 & 4,00 & 0,80 \\
\hline 3. Kemampuan konsumen & 0,10 & 3,00 & 0,30 \\
\hline 4. Pemasok yang berkualitas & 0,15 & 4,00 & 0,60 \\
\hline ANCAMAN & \multicolumn{1}{|l|}{} \\
\hline 1. Keberadaan gerai yang sejenis & 0,10 & 2,00 & 0,20 \\
\hline 2. Perusahaan pendatang baru & 0,10 & 2,00 & 0,20 \\
\hline 3. Paradigma masyarakat tentang makanan siap saji & 0,15 & 1,00 & 0,15 \\
\hline TOTAL & 1,00 & & 3,05 \\
\hline
\end{tabular}

\section{Matriks SWOT}

Setelah melakukan analisis faktor internal dan eksternal maka dapat dirumuskan ke dalam matriks SWOT yang menggambarkan setiap kekuatan, kelemahan, kesempatan, serta tantangan dari perusahaan. Berdasarkan kekuatan dan kelemahan internal serta peluang dan ancaman, perusahaan dapat mengambil empat kemungkinan alternatif strategis dalam 
menghadapi persaingan yang semakin

Keempat alternatif tersebut adalah :

kompetitif, seperti pada Tabel 3 Matriks SWOT.

Tabel 3. Matriks SWOT

\begin{tabular}{|c|c|c|}
\hline Faktor & \begin{tabular}{ll}
\multicolumn{2}{l}{ Kekuatan $(\mathrm{S})$} \\
1. & Kualitas produk \\
2. & Variasi produk \\
3. & Harga bersaing \\
4. & Kualitas pelayanan
\end{tabular} & $\begin{array}{ll}\text { Kelemahan }(\mathrm{W}) \\
1 . & \text { Kurangnya promosi } \\
2 . & \text { Kurangnya varian menu } \\
\text { 3. } & \text { Kurangnya jumlah gerai }\end{array}$ \\
\hline $\begin{array}{ll}\text { Peluang }(\mathrm{O}) \\
1 . & \begin{array}{l}\text { Kebutuhan masyarakat kota } \\
\text { Surabaya akan produk yang } \\
\text { praktis }\end{array} \\
2 . & \text { Perubahan perilaku dan } \\
& \text { selera konsumen yang } \\
\text { semakin berkembang } \\
\text { 3. } & \text { Kemampuan konsumen } \\
\text { 4. } & \text { Pemasok yang berkualitas }\end{array}$ & 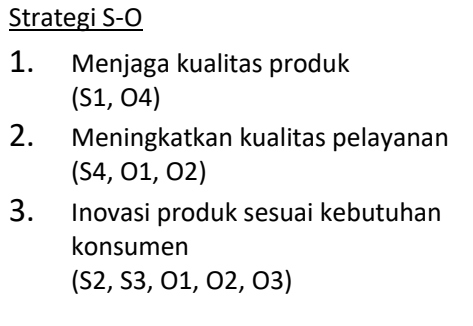 & $\begin{array}{ll}\text { Strategi W-O } \\
\text { 1. }\end{array}$ \\
\hline $\begin{array}{ll}\text { Ancaman }(T) \\
1 . & \text { Keberadaan gerai yang sejenis } \\
\text { 2. } & \text { Perusahaan pendatang baru } \\
\text { 3. } & \text { Paradigma masyarakat } \\
& \text { tentang makanan siap saji }\end{array}$ & $\begin{array}{l}\text { Strategi S-T } \\
\text { 1. } \begin{array}{l}\text { Mempertahankan ciri khas produk } \\
\text { dan pengembangan produk baru }\end{array} \\
\begin{array}{l}\text { (S1, S2, T1, T2) } \\
2 .\end{array} \begin{array}{l}\text { Meningkatkan hubungan baik } \\
\text { dengan pelanggan } \\
(\mathrm{S} 1, \mathrm{~S} 4, \mathrm{~T} 3)\end{array}\end{array}$ & $\begin{array}{l}\text { Strategi W-T } \\
\text { 1. } \\
\text { Menambah jumlah gerai, varian } \\
\text { (W1, W2, W3, T1, T2, T3) }\end{array}$ \\
\hline
\end{tabular}

1. Strategi S-O.

a. Menjaga kualitas produk. Pengawasan mutu yang telah dilakukan harus konsisten dijalankan. Pengawasan pada pemasok harus lebih ditingkatkan guna memastikan produk masih sesuai dengan spesifikasi Circle K.

b. Meningkatkan kualitas pelayanan. Kecepatan dalam persiapan makanan siap saji bisa menjadi kunci dalam peningkatan kualitas pelayanan guna mengimbangi aktivitas tinggi dengan waktu yang terbatas dari konsumen.

c. Inovasi produk sesuai kebutuhan konsumen. Circle $K$ hendaknya mengembangkan varian dari produk makanan siap saji sehingga dapat menarik selera konsumen dan tidak menyebabkan konsumen bosan, dengan harga yang masih terjangkau sesuai dengan kemampuan konsumen.

2. Strategi W-O.

a. Menambah jumlah gerai dan memanfaatkan media promosi. Penambahan gerai Circle $K$ guna mendekatkan Circle $K$ pada konsumennya, sehingga memudahkan konsumen untuk mendapatkan makanan siap saji. Circle $K$ harus bisa memanfaatkan media yang ada guna mengenalkan makanan siap sajinya.

b. Menambah variasi menu dengan harga yang terjangkau. Circle $K$ perlu menambah variasi makanan siap saji sesuai dengan selera konsumen. Produk yang telah ada merupakan produk tidak berkuah, sehingga perlu dilakukan penambahan menu makanan yang berkuah.

3. Strategi S-T.

a. Mempertahankan ciri khas produk dan pengembangan produk baru. Circle $K$ harus terus mengembangkan makanan siap saji guna menghadapi persaingan, dengan tetap mempertahankan ciri khas makanan siap saji yang telah ada, yaitu kepraktisan, kemudahan, dan kecepatan dalam persiapan.

b. Meningkatkan hubungan baik dengan pelanggan. Circle $K$ harus mampu memberikan pelayanan yang baik kepada konsumen dan harus bisa memberikan pemahaman bahwa makanan siap saji yang dijualnya mempunyai kualitas dan nilai gizi yang baik.

4. Strategi W-T.

a. Menambah jumlah gerai, varian menu dan variasi promosi. Circle $K$ harus 
terus berkembang dengan cara menambah gerai guna memudahkan konsumen untuk mencapai gerainya dan mendapatkan makanan siap sajinya, serta melakukan penambahan varian menu mencegah kebosanan konsumen dan didukung kegiatan promosi yang lebih bervariasi sehingga menarik minat konsumen. Hal tersebut guna menjaga loyalitas konsumennya.

\section{KESIMPULAN DAN SARAN}

Berdasarkan pembahasan, maka diperoleh kesimpulan sebagai berikut :

- Berdasarkan segmentasi demografis mayoritas konsumen berjenis kelamin perempuan, berusia 15 - 25 tahun, berpendidikan terakhir SMU, belum menikah, bekerja sebagai karyawan. Berdasarkan segmentasi geografis, mayoritas konsumen berasal dari Kota Surabaya. Berdasarkan segmentasi perilaku, mayoritas konsumen mengetahui adanya makanan siap saji private label di Circle $K$ lewat teman, membeli dengan tujuan untuk mencobacoba, membeli guna keperluan untuk makan, membeli sekali dalam seminggu, mempunyai kebiasaaan membeli dengan cara mencoba yang baru, membeli dan atau mengkonsumsi dengan ditemani oleh teman, dan bersedia merekomendasikan makanan siap saji.

- Berdasarkan segementasi psikografis sebagian besar konsumen masuk dalam cluster 1 (54,00\%), yaitu konsumen yang berminat membeli dan atau mengkonsumsi makanan siap saji setelah mengetahuinya, tidak mudah bosan dengan makanan siap saji, lebih menyukai mengkonsumsi makanan siap saji daripada makan di depot, makanan siap saji selalu tersedia atau jarang kosong pada saat mereka memerlukannya. Mereka melihat merek makanan siap saji mudah diingat, menu yang tersedia merupakan menu favorit, kegiatan promosi menarik, kemasan yang menarik dan tidak mudah rusak, etiket dan tanggal masa kadaluarsa yang jelas terlihat dan mudah dibaca, harga yang terjangkau dan sebanding dengan kualitasnya. Mereka menanggapi positif makanan siap saji sebagai makanan yang sehat dan bergizi, mempunyai kualitas dan nilai gizi yang baik, tidak membuat gemuk, dapat dikonsumsi oleh semua konsumen di segala usia, terjamin kebersihannya, dan mempunyai porsi yang cukup untuk sekali makan.

Beberapa saran yang dimunculkan adalah :

- Circle $K$ hendaknya melakukan pengembangan menu baru, seperti menu makanan siap saji yang berkuah.

- Circle $K$ hendaknya lebih meningkatkan peran pramuniaga agar lebih sering mempromosikan produk private label makanan siap saji kepada konsumen yang datang ke gerai Circle $K$.

- Perlunya informasi nilai gizi yang jelas dan detail pada kemasan guna menumbuhkan kepercayaan konsumen, khususnya konsumen yang menjaga kesehatan

- Perlunya penambahan gerai Circle $K$ di lokasi yang strategis guna mendekatkan Circle $K$ dengan konsumennya.

- Bagi penelitian selanjutnya perlu dilakukan penelitian dengan areal yang lebih luas, mengingat lokasi gerai Circle $K$ juga terdapat di beberapa kota besar di Indonesia, seperti Bali, Yogyakarta, Bandung, Jakarta, dan Ujung Pandang.

\section{DAFTAR PUSTAKA}

[1] Vijayabaskar, M. and Sundaram, N. 2012 . A Market Study on Key Determinants of Readyto-Eat/Cook Products with Respect to Tier-I Cities in Southern India. Zenith : International Journal of Multidisciplinary Research volume 2 (6) : 168-180.

[2] Tjandrasa, B. B. 2006 . Potensi Keuntungan Private Label serta Proses Pemilihan Produk dan Pemasoknya pada Bisnis Ritel . Jurnal Manajemen volume 6 (1) : 35-40.

[3] Susanti, R. 2012 . Produk Private Labels Brands sebagai Alternatif Meraih Konsumen pada Perusahaan Ritel . Jurnal Ekonomi dan Kewirausahaan volume 12 (1) : 76-84.

[4] Kotler, P. and Keller, K.L. 2012 . Marketing Management 14e Global Edition. Pearson Education Limited. Essex.

[5] Adiyoga, W. , Ameriana, M. dan Soetiarso . 2008 . Segmentasi Pasar dan Pemetaan Persepsi Atribut Produk Beberapa Jenis Sayuran Minor (Under-utilized) . Jurnal Hort volume 18 (4) : 466-476.

[6] Malhotra, N.K. 2007 . Marketing Research : an Applied Orientation Fifth Edition. Pearson Education International. New Jersey. 